\title{
From the Editorial Board
}

The scholarly journal presented here, entitled Studia Ceranea. Journal of the Waldemar Ceran Research Centre for the History and Culture of the Mediterranean Area and South-East Europe, is a periodical supervised by the above-mentioned institution - Ceraneum for short - a unit brought to life by decision of the Senate of the University of Łódź in February 2011.

Professor Waldemar Ceran (1936-2009) was among the most prominent figures in the Polish humanities, especially in the field of Byzantine studies. He was for many years the director of first the Department, then the Chair of Byzantine History, University of Łódź - the first and largest of such academic units in Poland. Throughout his long-lasting and prosperous academic career, he performed a number of significant duties. In particular, he was the director of the Institute of History, University of Łódź, as well as the president (subsequently honorary president) of the Commission of Byzantine Studies at the Committee of Ancient Culture, Polish Academy of Sciences (the Polish national committee of the Association Internationale des Etudes Byzantines). He was the immediate student and closest collaborator of Prof. Halina Evert-Kappesowa, the doyen of Byzantine studies in Łódź. He received substantial specialized training from such foreign masters of the field as Prof. Paul Lemerle or Prof. Nina V. Pigulevskaya. Professor Ceran, an expert on the history of the Byzantine Empire in its entire temporal extent and diverse aspects, specialized in the history of Antioch during Late Antiquity, the relations between the Church and the Byzantine state as well as the history of the Mount Athos monasteries. An outstanding polymath and enthusiast of the classical languages. An unparalleled speaker and lecturer. An indefatigable propagator of ancient and medieval history (especially of the Byzantine Empire). An exceptionally well-mannered man of amiable disposition. An idol and mentor of a whole group of scholars, reviewer of numerous doctoral, habilitation and professorial theses. Thus, the decision to name the newly founded Centre after Him seemed only natural to the founding members. Besides, the creation of Ceraneum in a way fulfils the aspirations of Professor Ceran himself. He devoted all his life to developing the Byzantine studies community in Poland and popularizing the research on the history of the Eastern Roman Empire.

The founders of Ceraneum, as well as of the newly created journal, are the employees of two academic units of the Univeristy of Łódź: the Department of Byzantine History and the Unit of Palaeoslavistic Studies and Folk Culture. The cooperation of the two units started in 2008 and was originally connected with organizing a se- 
ries of open lectures, aimed at presenting the scholars' research to a wider audience as well as at inviting the leading Polish and European authorities on Byzantine and Palaeoslavistic studies. So far, fourteen such lectures have been arranged. The noticeable interest they have aroused (not only among the teaching staff, but also the students and doctoral students of the University of Łódź), as well as the integration of the Łódź communities of specialists in history and Slavic studies that they have brought about, have caused the contacts to intensify and develop into a closer form of partnership. Specifically, a decision was made to form an interdepartmental research unit, designed to investigate the broadly defined history, religion and culture of the Mediterranean Basin, especially the area of the Byzantine Empire and Slavia Orthodoxa. To this end, the scope of the unit's research interests was extended so as to include other disciplines from among the humanities and the social sciences.

As a result, the application to found the interdepartmental Centre was filed to the Senate of the University of Łódź by the deans of as many as four faculties: the Faculty of Philosophy and History, the Faculty of Philology, the Faculty of International and Political Studies and the Faculty of Law and Administration. The basic tenet of the founders of Ceraneum is the interdisciplinary character of scientific inquiries, linking diverse fields of research and encompassing miscellaneous methodological principles. These objectives likewise apply to the scientific journal under discussion. Thanks to this, we hope to arrive at a more holistic perspective of the history of the aforementioned geographic/cultural region, as well as to provide scholars working on different aspects of history and culture with an opportunity of a direct exchange of ideas, both within Ceraneum itself and in the associated publications.

In order to live up to these assumptions, the activities centred around Ceraneum are to include editing the yearly Studia Ceranea alongside a series of monographs (Seria Ceranea), as well as organizing meetings (conferences, symposia etc.) designed to integrate the community of specialists studying the history of the Byzantine Empire and the South and East Slavs. The scholarly level and the objects of the research conducted will be supervised by the Advisory Board of Ceraneum, created by decision of the Rector of the University of Łódź. The board comprises several dozen distinguished scholars from various European research centres (including Oxford, Cambridge, Paris, Vienna, Berlin, Rome, Sofia, Belgrade and Moscow). Moreover, the members of the editorial council of Studia Ceranea (similarly conceived as an international body, comprising scholars from Poland and abroad) have already been appointed.

The first volume of Studia Ceranea is including the above-mentioned lectures delivered at the University of Łódź by the members of both founding units, as well as the Polish and international guests. In this manner, readers will have the chance to acquaint themselves with the results of almost three years of organizational and editorial effort of the members of the Department of Byzantine History and the Unit of Palaeoslavistic Studies and Folk Culture. Thus, the texts have been presented here in 
chronological order, reflecting the pace of our co-operation (from Maciej Kokoszko's lecture delivered 17 XII 2008 to Ivelin Ivanov's given 24 V 2011).

Studia Ceranea being designed as an international journal, contributions in the standard conference languages will be accepted (English, French, German, Russian and Italian). In the era of an absolute domination of the English language, which is slowly becoming the lingua franca of all kinds of scientific research, it was our intention not to abandon the centuries-long linguistic traditions of the European humanities. In this fashion, we expect to honour the heritage of the most significant national schools in the relevant fields of study, as well as the linguistic sensitivity of the contributing scholars, stemming from diverse scientific communities, not all of which prefer English as the basic code of communication. This is also an expression of our profound conviction that the disciplines we are interested in require a solid command of at least the few most crucial languages in which the research on the Eastern Roman Empire has been carried out. Furthermore, we have resolved to accept papers pertaining to the history of the Mediterranean and the Slavic area within the chronological limits from the $1^{\text {st }}$ through the $17^{\text {th }}$ century AD. Thus, the task that the editorial council of Studia Ceranea has set before itself is the gradual creation of a scientific journal, interdisciplinary in character, which will offer specialist articles, reviews and notes on newly published monographs. Along these lines, we will attempt to cross the limits of the narrow specializations restricted to Byzantine or Slavic studies; the papers contributed would represent various aspects of the Late Ancient, Byzantine and Slavic culture of the Mediterranean Area and South-East Europe, which - we claim - forms an integrity, for all its diversity. Consequently, Studia Ceranea, relying on the respectable earlier models provided by other periodicals devoted to similar issues, will endeavour to utilize the methodology and achievements of related disciplines employed in the studies on Late Antiquity, the Middle Ages and the Modern Era. The journal is ready to face the challenges associated with contemporary humanistic thinking.

We wish to express our sincere hope that the yearly Studia Ceranea. Journal of the Waldemar Ceran Research Centre for the History and Culture of the Mediterranean Area and South-East Europe will arise interest among the international scholarly community, effectively becoming a forum for exchanging information and a vehicle of academic discussion.

We cordially invite all interested Readers to future meetings on the pages of Studia Ceranea.

Georgi Minczew

Mirosław J. Leszka

Małgorzata Skowronek

Kirił Marinow

Andrzej Kompa

Karolina Krzeszewska 